Для чего использовались растворы цитрата аммония (40\%), трилона Б $(0,1 \mathrm{M})$, аммиака (1:1), диэтилдитиокарбамата натрия (1\%).

Перед исследованием зависимости регенерации катионита от концентрации серной кислоты, проводили сорбцию ионов меди катионитом. После проведения ионного обмена катионит регенерировали растворами серной кислоты 2,$5 ; 5$; 7,5; 10\%-ой концентраций со скоростью 5 мл/мин.

Результаты исследования показали, что процесс десорбции при пропускании 5 \%-ого раствора серной кислоты идет наиболее быстро: на снижение концентрации меди в элюате менее 1 г/л потребовалось 300 мл $\mathrm{H}_{2} \mathrm{SO}_{4}$; при пропускании $2,5 \%$-ой серной кислоты на снижение концентрации меди в элюате менее 1 г/л потребовалось 550 мл $\mathrm{H}_{2} \mathrm{SO}_{4}$. Процессы регенерации 7,5 и 10 \%-ым растворами серной кислоты идут хуже, что, возможно, связано с процессом зашлаковывания в слое катионита.

На основании вышеизложенных результатов для исследования влияния скорости регенерации был выбран 5 \%-ый раствор серной кислоты, который пропускали через отработанный катионит со скоростями 20, 10 и 5 мл/мин.

Полученные данные показали, что при скоростях пропускания регенерирующего раствора 10 и 20 мл/мин не имеется значимых различий; процесс десорбции при скорости пропускания 5 мл/мин идет заметно быстрее, кроме того, на снижение концентрации меди в элюате до величины меньше 1 мг/л потребовалось 300 мл $\mathrm{H}_{2} \mathrm{SO}_{4}$, в то время как при скоростях 10 и 20 мл/мин - 550 мл.

Таким образом, с целью сокращения затрат серной кислоты на регенерацию и затрат на переработку элюатов процесс десорбции следует проводить раствором $5 \%$-ой серной кислоты с меньшей скоростью пропускания.

\title{
CHARACTERIZATION OF TiAISiON COATINGS DEPOSITED BY PLASMA ENHANCED MAGNETRON SPUTTERING: XRD, XPS, AND DFT STUDIES
}

Anokhin E.S. ${ }^{1}$, Zhidkov I.S. ${ }^{1}$, Kukharenko A.I. ${ }^{1}$, Chukin A.V. ${ }^{1}$, Cholakh S.O. ${ }^{1}$, Kurmaev E.Z. ${ }^{2}$, Skorikov N.A. ${ }^{2}$, Kamenetskih, A.S. ${ }^{1,3}$, Gavrilov, N.V. ${ }^{3}$

${ }^{1)}$ Ural Federal University, Yekaterinburg, Russia

${ }^{2)}$ M.N. Mikheev Institute of Metal Physics, RAS-Ural Division, Yekaterinburg, Russia

${ }^{3)}$ Institute of Electrophysics, RAS-Ural Division, Yekaterinburg, Russia

*E-mail: a.i.kukharenko@urfu.ru

Despite a comparatively low oxidation resistance (the oxidation onset is reported at $500{ }^{\circ} \mathrm{C}$ ), titanium nitride ( $\mathrm{TiN}$ ) coating is used widely in cutting tool applications to increase lifetime and to improve performances of cutting tools. It has been found that adding such elements as $\mathrm{Al}$ and $\mathrm{Si}$ leads to the formation of TiAlSiN composites, which are characterized by high hardness $(40 \mathrm{GPa}$ ) and great oxidation resistance (up to $800^{\circ} \mathrm{C}$ ). 
The results of characterization of TiAlSiON hard coatings deposited on ferricchromium AISI 430 stainless steel by plasma enhanced magnetron sputtering are presented. The coating with maximum hardness (of $43 \mathrm{GPa}$ ) was obtained at the following optimal values of elemental concentrations: $\mathrm{Si} \sim 5$ at.\%, $\mathrm{Al} \sim 15 \mathrm{at} . \%$, and $\mathrm{Ti}$ $\sim 27 \mathrm{at} . \%$. The value of gaseous mixture $\left(\mathrm{Ar}-\mathrm{N}_{2}\right)$ pressure was of $0.13 \mathrm{~Pa}$ and the value of partial pressure of oxygen $\left(\mathrm{O}_{2}\right)$ was $1.3 \cdot 10^{-3} \mathrm{~Pa}$.

The X-ray diffraction measurements showed the presence of $\mathrm{Ti}(\mathrm{Al}) \mathrm{N}$. Highenergy resolved XPS spectra of core levels revealed the formation of Ti-N, Ti-O-N, $\mathrm{Si}-\mathrm{N}$ and Al-O-N bonds.

Comparison of XPS valence band spectra with specially performed density functional theory calculations for disordered $\mathrm{Ti}_{0.5} \mathrm{Al}_{0.5} \mathrm{~N}_{1-\mathrm{x}} \mathrm{O}_{\mathrm{x}}(0 \leq \mathrm{x} \leq 0.3)$ phases demonstrated that a $\mathrm{Ti}(\mathrm{Al}) \mathrm{O}_{\mathrm{x}} \mathrm{N}_{\mathrm{y}}$ phase is formed on the surface of AISI430 steel upon the plasma enhanced magnetron sputtering, which can provide a good combination of high hardness and additional oxidation resistance of this material.

\title{
РАССЕЯНИЕ УЛЬТРАКОРОТКИХ ИМПУЛЬСОВ ЭЛЕКТРОМАГНИТНОГО ПОЛЯ НА НАНОСИСТЕМАХ С ДЕФЕКТАМИ В ЗАДАЧАХ РЕНТГЕНОСТРУКТУРНОГО АНАЛИЗА
}

\author{
Макаров Д.Н., , Матвеев В.И.
}

Северный(Арктический) федеральный университет им. М.В. Ломоносова, г. Архангельск, Россия

*E-mail: makarovd0608@yandex.ru

\section{SCATTERING OF ULTRASHORT PULSES OF ELECTROMAGNETIC FIELD BY NANOSYSTEMS WITH DEFECTS FOR THE GOALS OF X-RAY DIFFRACTION ANALYSIS}

\author{
Makarov D.N. ${ }^{*}$, Matveev V.I.
}

Northern (Arctic) Federal University, Arkhangelsk, Russia

The influence of defects in nanostructured targets on interference spectra for reradiation of attosecond pulses of electromagnetic field is considered. The general expressions are obtained for the spectral distributions of one-dimensional, two-dimensional and threedimensional nanosystems with complex defects such as bends, breaks and vacancies.

Кристаллы и наноструктурированные мишени представляют собой естественные дифракционные решетки для рентгеновского излучения. В рентгеноструктурном анализе явление дифракции рентгеновских лучей на различные рода периодических структурах обычно описывается как рассеяние плоских волн бесконечной длительности по времени [1]. Процессы же рассеяния аттосекундных импульсов электромагнитного поля на такого рода структурах до настоящего времени мало исследованы. Хотя подобные процессы могут дополнить рент- 